\title{
THE EFFECT OF INFLATION ON THE NUMBER OF MEDIUM SMALL MICRO ENTERPRISES (MSMEs) 2016 - 2019 IN SUKOHARJO REGENCY
}

\author{
Sulistiyono ${ }^{1)}$, Irma Nuriyaningsih ${ }^{2)}$, Frisca Nastasya Fiorentina ${ }^{3)}$, Gustita Arnawati Putri ${ }^{4)}$ \\ ${ }^{1,2,3,4)}$ Veteran Bangun Nusantara University, Sukoharjo, Indonesia \\ Corresponding author: gustitaarnawati@univetbantara.ac.id
}

\begin{abstract}
Inflation, in brief, has the meaning of a tendency to increase the prices of goods and services in general and continuously. Inflation will affect macroeconomic activities, micro, and investment activities. This inflationary condition is also bothersome for producers as owners of Micro, Small, and Medium Enterprises (MSMEs). In 2016, the number of MSMEs in the Sukoharjo Regency was 11,187 and increased in 2019 by 20,030. However, the increase in the number of MSMEs is, in fact, inversely related to the decreasing inflation rate. In 2016 the inflation rate was 2.34\%, and in 2019 the inflation rate was $2.13 \%$. The sample used in this study were all MSMEs registered at the Industry and Trade Service (Disperindag) of Sukoharjo Regency in 2016-2019. the number of MSMEs in the Regency increased. In 2017 there were 19,804 units, then to 20,580 in 2018. The increase was 8,617 pieces per year. The results of the data analysis show that inflation has an effect on the number of MSME players in Sukoharjo Regency. This means that the higher the inflation rate, the number of Micro, Small, and Medium Enterprises players will decrease.
\end{abstract}

Keywords: Inflation; Micro, Small and Medium Enterprises (MSMEs), Sukoharjo Regency

\section{Introduction}

Sukoharjo Regency is one of the regencies in Central Java Province, with an area of about 46,666 ha. Sukoharjo Regency has excellent prospects in the business sector due to the location of Sukoharjo Regency, which is close to the City of Surakarta. Economic growth in 2018, as indicated by the growth rate of Gross Regional Domestic Product (GRDP) at constant 2010 prices, was higher than the previous year, namely $5.82 \%(2017=5.76 \%)$. Real sectoral growth in 2018 fluctuated of the prior year (BPS Sukoharjo Regency, 2019). The increase in GRDP is directly proportional to data from the Trade Cooperative and Small and Medium Enterprises Office of Sukoharjo Regency, which shows that from 2016 to 2019, the condition of Micro, Small, and Medium Enterprises (MSMEs) has increased. Data in 2016 shows that the number of MSMEs is 11,187, and in 2019 the number is 20,030 (Dispendag \& UKM, 2019). However, the increase in the number of MSMEs is inversely proportional to the data obtained from BPS Sukoharjo Regency, which shows that from 2016 to 2019, the inflation rate has decreased. The inflation rate in 2016 was $2.34 \%$, and in 2019 it was $2.13 \%$. The increase in MSMEs every year encourages researchers to find out more about the growth of MSMEs in Sukoharjo Regency.

Inflation defines as "an increase in the average price level, and the price is the rate at which money is needed to obtain goods and services"(Gregory, 2007). This inflationary state can disrupt the economy, especially producers, as owners of MSMEs. The occurrence of inflation often hurts the turnover of MSMEs so that MSME owners have to seek additional income by creating innovations in various MSME products. Inflation that occurs can change the revenue (turnover) of MSMEs, which is profitable or detrimental. In some conditions, inflation can boost economic growth by encouraging MSME entrepreneurs to expand their production. This will create two job opportunities, as well as increase the income of MSME owners. If you look at the perspective of the Indonesian people, inflation often harms the lower class society so that there is criticism against the government for making inappropriate policies that cause inflation to continue to rise. Even the slightest inflation often creates problems. Therefore, the role of the government is to intervene in policy, so the government must provide equal public needs for all Indonesian people (Rosa,2019).

\section{Literature Review Micro, Small and Medium Enterprises (MSMEs)}

Micro, Small, and Medium Enterprises (MSMEs), according to Law No.20 of 2008, explains that MSMEs are: 1. Micro enterprises are productive businesses owned by individuals or individual business entities that meet the criteria. 2. Small Business is a productive economic business that stands alone, which is carried out by an individual or business entity that is not a subsidiary or branch of a company that is owned, controlled, or is a part, either directly or indirectly, of Medium or Large Business criteria. 3. Medium business is a productive economic business that stands alone, which is carried out by individuals or business entities that are not subsidiaries or branches of companies that are owned, controlled, or are part of, either directly or indirectly, with Small or Large Businesses with total assets: net or annual sales proceeds. About efforts to maintain purchasing power, the government must increase economic growth as well as public demand so that people's purchasing power from the MSME side rises. The challenges faced by MSMEs in line with the weakening of people's purchasing power are still considerable because some MSME players 
have switched to online trading. Besides that, MSMEs have not been able to create effective marketing because it is not easy to change from business platforms to other platforms.

The government has reduced the MSME tax by only $0.5 \%$ following PP No.23 of 2018 concerning Income Tax on Business Income Received or Earned by Taxpayers with Certain Gross Circulation. The enactment of this PP is intended to encourage the public to participate in economic activities by providing convenience and simplicity for MSME players in carrying out their tax obligations. With the determination of this new rate, the tax burden borne by MSME actors becomes smaller so that MSME actors have a greater economic capacity to develop. Venture and invest. Besides, this PP is also expected to be able to provide time for MSME actors to prepare themselves before taxpayers exercise their rights and tax obligations in general according to the provisions of the income tax law. The benefits of 5\% PPh UMKM are as follows: (1) MSMEs can pay taxes quickly and only because of tax calculations (2) offline and online MSMEs by adding up the gross circulation in a month, then multiply by the rate. It can reduce the tax burden of MSME actors because, with low speeds, the remaining (3) net turnover after tax can be used by entrepreneurs to develop their business. Low tax rates can stimulate people to become entrepreneurs because they do not (4) need to worry about high tax burdens.

\section{Inflation}

Inflation, in brief, can be interpreted as a tendency to increase the prices of goods and services in general and continuously. In this sense, two essential definitions are the key to understanding inflation. The first is a general increase in prices, and the second is continuous. Inflation must contain an element of price increases, and then the price increase is the price in general. Only price increases that occur in general can be referred to as inflation(Astiyah, 2009). Inflation is "an increase in the average price level and the price is the rate at which money is needed to obtain goods and services"(Gregory, 2007).

Inflation will affect both macro and micro economic activities, including investment activities. Inflation also causes a decrease in people's purchasing power which results in a decrease in sales. The decline in sales that occurs can reduce the company's return. The decline in return that occurs will affect the company's ability to pay installments. Installment payments that are increasingly inaccurate cause the quality of financing to get worse and even bad financing occurs, thus increasing the NPF presentation (Suyanto, 2017).

Based on the theoretical basis described, the research hypothesis is as follows:

H1: There is a significant effect of the inflation rate on the number of Micro, Small and Medium Enterprises

(MSMEs) entrepreneurs.

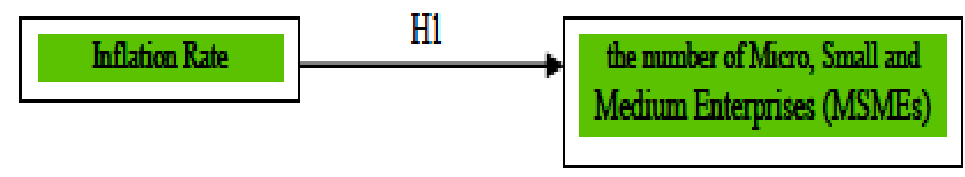

Figure 1. Hypothesis Framework.

\section{Research Methods \\ Population and Sample}

The population used in this study were MSMEs in Sukoharjo Regency from 2016 to 2019. In this study, the sample selection was carried out using a purposive sampling method, namely a non-random sample selection technique whose information was obtained using specific criteria. The criteria for sampling are as follows:

- MSMEs that have been registered with the Office of Trade, Cooperatives and Micro, Small and Medium Enterprises, Sukoharjo Regency.

- At least MSMEs have been operating since the year the research was conducted (2016 - 2019 period).

\section{Operational Definition and Variable Measurement}

Dependent variable; the dependent variable in this study is the number of MSME actors Independent variable; the independent variable in this study is inflation

\section{Result and Discusssion \\ Overview of MSMEs in Sukoharjo Regency}

Data from the Sukoharjo Regency Koperasi and UMKM Office in 2019, the number of MSMEs in the Regency increased. In 2017 there were 19,804 units, then to 20,580 in 2018. The increase was 8,617 pieces per year. The number of MSME actors per district is presented in the following table. 
Table 1. Number of MSME Players per District of Sukoharjo Regency

\begin{tabular}{clcccc}
\hline No & & 2016 & 2017 & 2018 & 2019 \\
\hline 1 & KecamatanWeru & 1.273 & 1.751 & 1.787 & 2.209 \\
\hline 2 & Kecamatan Bulu & 349 & 716 & 748 & 736 \\
\hline 3 & KecamatanTawangsari & 233 & 678 & 736 & 748 \\
\hline 4 & Kecamatan Sukoharjo & 1.288 & 2.155 & 2.209 & 2.157 \\
\hline 5 & Kecamatan Nguter & 780 & 1.490 & 1.545 & 1.787 \\
\hline 6 & Kecamatan Bendosari & 884 & 1.617 & 1.681 & 1.545 \\
\hline 7 & Kecamatan Polokarto & 652 & 1.081 & 1.182 & 1.182 \\
\hline 8 & Kecamatan Mojolaban & 1.828 & 2.219 & 2.377 & 2.377 \\
\hline 9 & Kecamatan Grogol & 784 & 2.082 & 2.157 & 1.526 \\
\hline 10 & Kecamatan Baki & 968 & 1.469 & 1.526 & 1.681 \\
\hline 11 & Kecamatan Gatak & 1.561 & 2.696 & 2.734 & 2.734 \\
\hline 12 & Kecamatan Kartasura & 587 & 1.850 & 1.898 & 1.898 \\
\hline & Total & $\mathbf{1 1 . 1 8 7}$ & $\mathbf{1 9 . 8 0 4}$ & $\mathbf{2 0 . 5 8 0}$ & $\mathbf{2 0 . 5 8 0}$ \\
\hline
\end{tabular}

Table 2. Number of MSME Players in Sukoharjo Regency 2015 - 2018

\begin{tabular}{ccccc}
\hline Tahun & Micro & Small & Medium & Total \\
\hline 2015 & 5.510 & 4.460 & 1.155 & $\mathbf{1 1 . 1 2 5}$ \\
\hline 2016 & 5.566 & 4.465 & 1.156 & $\mathbf{1 1 . 1 8 7}$ \\
\hline 2017 & 12.616 & 5.222 & 1.966 & $\mathbf{1 9 . 8 0 4}$ \\
\hline 2018 & 13.074 & 5.533 & 1.973 & $\mathbf{2 0 . 5 8 0}$ \\
\hline
\end{tabular}

Table 3. ANOVA

\begin{tabular}{lrrrrr}
\hline Model & Sum of Squares & Df & Mean Square & F & \multicolumn{1}{c}{ Sig. } \\
\hline Regression & 3122559.714 & 1 & 3122559.714 & 7.942 & $.007^{\mathrm{a}}$ \\
Residual & $1.809 \mathrm{E} 7$ & 46 & 393175.962 & & \\
Total & $2.121 \mathrm{E} 7$ & 47 & & & \\
\hline
\end{tabular}

a. Predictors: (Constant), X

b. Dependent Variable: Y

Judging from the test results above, with an $\mathrm{f}$ table value of 4.05 and a probability level of 0.05 , it can be seen that the significance value of the influence of $\mathrm{X}$ on $\mathrm{Y}$ is $0.007<0.05$, and the amount of $\mathrm{F}$ counts is 7.942> F table 4.05, so it can be concluded that the hypothesis is accepted which means there is the effect of $\mathrm{X}$ (inflation) simultaneously on Y (MSME).

\section{Conclusion}

The number of MSMEs registered with the Trade Cooperative and Micro, Small, and Medium Enterprises Office of Sukoharjo Regency until 2019 was 20,580 MSMEs. Meanwhile, the inflation data used in the study were obtained from the Central Statistics Agency of Sukoharjo Regency. The inflation data used is inflation data per year. Meanwhile, the UMKM data used was data per district in Sukoharjo Regency. Based on the data obtained, the total observations used as the object of this study were 48 statements over four years. The hypothesis which states that inflation has an effect on the number of Micro, Small, and Medium Enterprises actors in Sukoharjo Regency is accepted. These results indicate that inflation has an influence on the number of Micro, Small, and Medium Enterprises actors in Sukoharjo Regency. This means that the higher the inflation rate, the number of Micro, Small, and Medium Enterprises players will decrease. Vice versa, the lower the inflation rate, the higher the number of Micro, Small, and Medium Enterprises actors.

\section{References}

Journal Articles

Idwar, Yenni Del Rosa. 2019. Pengaruh Inflasi dan Suku Bunga Terhadap Omset UMKM Kota Padang. Jurnal Menara ekonomi Pelayiha dan Kajian Bidang ekonomi Volume No. 3.

Laelasari, Wulan. 2019. Pengaruh Inflasi Terhadap Pembiayaan Usaha Mikro Kecil Menengah (UMKM) Tahun 2015 - 2016 di BPRS Al-Masoem. Jurnal Sains Manajemen dan Akuntansi Volume XI No. 1.

Wahiddudin, Mohammad. 2018. Pengaruh Inflasi, Non Performing Financing (NPF) dan BI Rate Terhadap

Pembiayaan Usaha Mikro Kecil Menengah (UMKM) Pada Bank Umum Syariah 2012-2017. Jurnal Al Amwal Volume 1 No.1.

Books

Mankiw, N. Gregory. 2007. Principle of Economics, Pengantar Ekonomi Makro. Edisi Tiga. Jakarta: Salemba Empat. 
Sekaran, U. 2006. Research Method for Business. USA: John Wiley\&Sons.Inc Sunyoto, D. 2011. Analisis Regresi dan Uji Hipotesis. Yogyakarta : CAPS

Suseno, Siti Astiyah. 2009. Inflasi. Jakarta: Pusat Pendidikan dan Studi Kebanksentralan (PPSK).

Suyanto. 2017. Data Mining Untuk Klasifikasi Dan Klasterisasi Data. Bandung: Informatika Bandung.

Undang-undang No.20 Tahun 2008 Tentang Usaha Mikro Kecil Menengah (UMKM).

Badan Pusat Statistika (BPS) Kabupaten Sukoharjo. https://sukoharjokab.bps.go.id/.

Bank Indonesia. 2019. Statistik Pertumbuhan Inflasi, 2012-201. www.bi.go.id

Dinas Perindustrian dan Perdagangan (Desperindag) Kabupaten Sukoharjo.

http://dpkukm.sukoharjokab.go.id/.

Fakultas Ekonomi Universitas Veteran Bangun Nusantara Sukoharjowww.manajemen.fe.univetbantara.ac.id. 